\title{
GROUNDWATER FLOW NEAR THE SHOAL SITE, SAND SPRINGS RANGE, NEVADA: IMPACT OF DENSITY-DRIVEN FLOW
}

\author{
Prepared by \\ Jenny Chapman, Todd Mihevc, and Alan McKay
}

Submitted to

Nevada Operations Office

U.S. Department of Energy

Las Vegas, Nevada

September 1994 
This report was prepared as an account of work sponsored by the United States Government. Neither the United States nor the United States Department of Energy, nor any of their employees, makes any warranty, express or implied, or assumes any legal liability or responsibility for the accuracy, completeness or usefulness of any information, apparatus, product or process disclosed, or represents that its use would not infringe privately owned rights. Reference herein to any specific commercial product, process, or service by trade name, mark, manufacturer, or otherwise, does not necessarily constitute or imply its endorsement, recommendation, or favoring by the United States Government or any agency thereof. The views and opinions of authors expressed herein do not necessarily state or reflect those of the United States Government or any agency thereof.

This report has been reproduced directly from the best available copy.

Available to DOE and DOE contractors from the Office of Scientific and Technical Information, P.O. Box 62, Oak Ridge, TN 37831; prices available from (615) 576-8401.

Available to the public from the National Technical Information Service, U.S. Department of Commerce, 5285 Port Royal Rd., Springfield, VA 22161. 


\section{DISCLAIMER}

Portions of this document may be illegible in electronic image products. Images are produced from the best available original document. 


\title{
GROUNDWATER FLOW NEAR THE SHOAL SITE, SAND SPRINGS RANGE, NEVADA: Impact of Density-Driven Flow
}

\author{
Prepared by \\ Jenny Chapman, Todd Mihevc, and Alan McKay \\ Water Resources Center \\ Desert Research Institute \\ University and Community College System of Nevada
}

Publication No. 45130

Submitted to

Nevada Operations Office

U.S. Department of Energy

Las Vegas, Nevada

September 1994

The work upon which this report is based was supported by the U.S. Department of Energy under Contract \#DE-AC08-90NV10845.

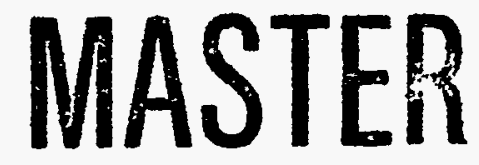




\begin{abstract}
The nature of flow from a highland recharge area in a mountain range in north-central $\mathrm{Ne}$ vada to discharge areas on either side of the range is evaluated to refine a conceptual model of contaminant transport from an underground nuclear test conducted beneath the range. The test, known as the Shoal event, was conducted in 1963 in granitic rocks of the Sand Springs Range. Sparse hydraulic head measurements from the early 1960s suggest flow from the shot location to the east to Fairview Valley, while hydrochemistry supports flow to salt pans in Fourmile Flat to the west. Chemical and isotopic data collected from water samples and during well-logging are best explained by a reflux brine system on the west side of the Sand Springs Range, rather than a typical local flow system where all flow occurs from recharge areas in the highlands to a central discharge area in a playa. Instead, dense saline water from the playa is apparently being driven toward the range by density contrasts. The data collected between the range and Fourmile Flat suggest the groundwater is a mixture of younger, fresher recharge water with older brine. Chemical contrasts between groundwater in the east and west valleys reflect the absence of reflux water in Fairview Valley because the regional discharge area is distant and thus there is no accumulation of salts. The refluxing hydraulic system probably developed after the end of the last pluvial period and differences between the location of the groundwater divide based on hydraulic and chemical indicators could reflect movement of the divide as the groundwater system adjusts to the new reflux condition.
\end{abstract}




\section{CONTENTS}

Abstract $\ldots \ldots \ldots \ldots \ldots \ldots \ldots \ldots \ldots \ldots \ldots \ldots \ldots \ldots \ldots \ldots \ldots \ldots \ldots \ldots \ldots \ldots \ldots$

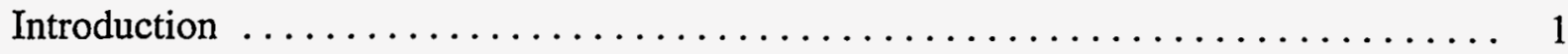

Approach $\ldots \ldots \ldots \ldots \ldots \ldots \ldots \ldots \ldots \ldots \ldots \ldots \ldots \ldots \ldots \ldots \ldots \ldots \ldots \ldots$

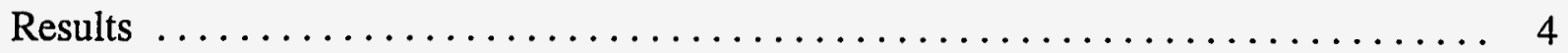

Conceptual Model of the Groundwater Flow System and Model of

Chemical Evolution $\ldots \ldots \ldots \ldots \ldots \ldots \ldots \ldots \ldots \ldots \ldots \ldots \ldots \ldots$

Fitting the Conceptual Model to the Site Data $\ldots \ldots \ldots \ldots \ldots \ldots \ldots \ldots \ldots$

The Refluxing Brine Model $\ldots \ldots \ldots \ldots \ldots \ldots \ldots \ldots \ldots \ldots \ldots \ldots \ldots \ldots$

Chemical and Logging Evidence for Reflux Water $\ldots \ldots \ldots \ldots \ldots \ldots \ldots \ldots$

Recharge Mechanisms $\ldots \ldots \ldots \ldots \ldots \ldots \ldots \ldots \ldots \ldots \ldots \ldots \ldots \ldots \ldots$

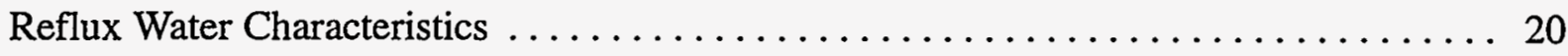

Implications of Reflux Brine on Transport from the Sand Springs Range $\ldots \ldots \ldots \ldots 21$

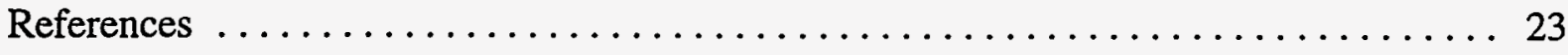




\section{FIGURES}

1. Map of the Sand Springs Range and vicinity showing the location of wells and

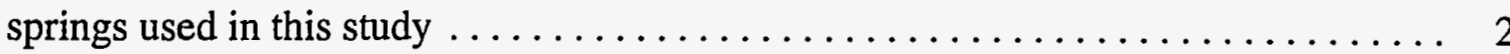

2. Idealized groundwater flow in a local system with notes for suggested land use,

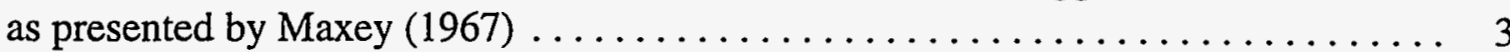

3. Piper diagram demonstrating the three hydrochemical facies in the samples collected for this study

4. Stable isotope composition of samples collected for this study $\ldots \ldots \ldots \ldots \ldots$

5. Temperature, conductivity, and $\mathrm{pH}$ logs from well $\mathrm{H}-2$, run on June $15,1993 \ldots \ldots 8$

6. Piper diagram of chemical analyses of water samples collected in the study region, published during investigation of the Shoal site prior to the nuclear test $\ldots \ldots \ldots \ldots 11$

7. Conceptual depiction of reflux brine west of the Sand Springs Range $\ldots \ldots \ldots \ldots 13$

8. $\delta \mathrm{D}$ plotted against chloride, with all samples shown on $8 \mathrm{~b}$, and a limited $\mathrm{Cl}$ range shown on $8 \mathrm{a}$

9. Carbon-14 plotted against $\delta D$, with uncorrected or "apparent" ages and ages corrected for addition of dead carbon assuming intial carbon-13 values

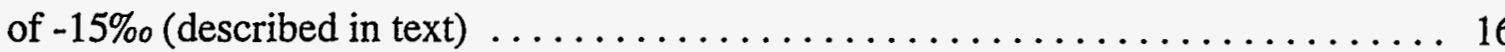

10. Stable isotope composition of samples from this study ("Shoal samples") plotted with stable isotope data from other wells and springs in the region, from University of Nevada (1980)

\section{TABLES}

1. Chemical Analyses of Water Samples Collected in the Area of

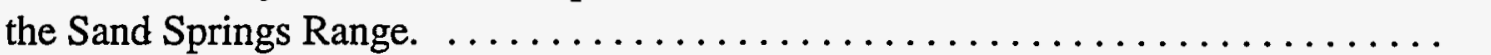

2. Carbon Isotope Analyses for Samples Collected in the Area of the Sand Springs Range. 


\section{INTRODUCTION}

Project Shoal was an underground nuclear test conducted by the U.S. government in west-central Nevada in 1963. The nuclear device was detonated approximately $366 \mathrm{~m}$ below ground surface within granitic rocks of the Sand Springs Range (U.S. AEC, 1964). The Sand Springs Range is a north-south trending uplift bounded by Fairview Valley on the east and and Fourmile Flat to the west (Figure 1). Typical of the Basin and Range physiographic province, there is steep topographic relief in excess of $300 \mathrm{~m}$ between the range and valleys. Groundwater occurs in fractured granite within the range, with flow into unconsolidated sediments in valleys on either side of the Sand Springs Range. The position of the resultant groundwater divide and thus the location of the test relative to the divide is uncertain (Nevada Bureau of Mines et al., 1965; Chapman and Hokett, 1991), leading to the possibility of contaminant transport to either the east or west. With water supply wells in both valleys and discharge of groundwater to the surface in the western valley, concerns about transport of radionuclides from the nuclear test through the groundwater system have been raised.

Hydrogeologic systems in the Great Basin have been divided into two general categories: regional and local (Maxey, 1967). The existence of large regional flow systems connecting topographically separate basins was first recognized in the 1960s (Eakin, 1965; Winograd, 1962) and such systems became the focus of much research (Winograd and Thordarson, 1975). Conversely, local systems were generally believed to approximate ideal groundwater flow systems where the water table conforms to topography and flow system boundaries correspond to topographic divides. Such systems should be relatively simple to understand, with highland recharge areas characterized by decreasing potentials with depth, an area of lateral flow topographically below the recharge zone but above the discharge area, and an area of discharge where water moves upward to the land surface (Figure 2).

The Sand Springs Range and adjoining valleys were highlighted by Maxey (1967) as a well-documented example of a local system. Maxey noted that hydraulic head measurements in wells drilled on the range established a groundwater divide closely approximating the topographic divide of the range and that groundwater potentials decreased with depth. Drilling on either side of the range yielded increasing potentials with depth, establishing discharge areas. The interpreted flow system contains arcing flow lines representing groundwater moving deep below the surface before coming up to the discharge zone, resulting in a long flow path between recharge and discharge areas. This depiction of the flow system is attractive from a contaminant transport perspective because radionuclides introduced to the groundwater in the recharge area at the Sand Springs Range must pass through the entire flow system before reappearing at the surface in the discharge area, allowing for ample dilution and sorption opportunities.

Recent research (Duffy and Al-Hassan, 1988; Herczeg et al., 1992) indicates that the preceding idealized situation does not always occur in local systems. In particular, the presence of brine-driven convection cells driven by density contrasts between groundwater in the lateral flow and discharge zones can complicate the otherwise simple flow system. Recharge occurs in the surrounding high elevation ranges and groundwater moves as shallow subsurface flow or surface runoff from springs 


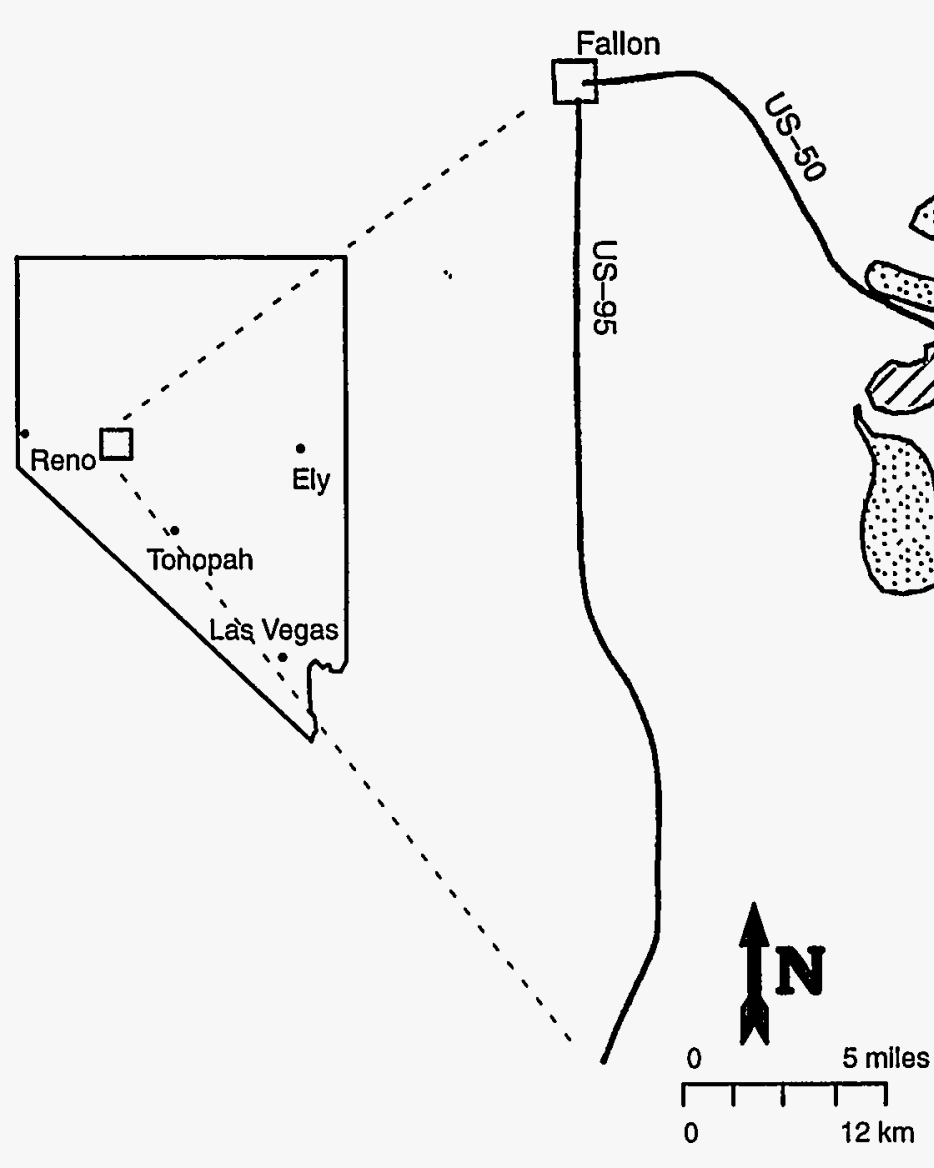

$\square$ Playa
Mountain Range $\square$ GZ (ground zero)

- Wells and springs in the Shoal area

Figure 1. Map of the Sand Springs Range and vicinity showing the location of wells and springs used in this study. "GZ" stands for ground zero and marks the location of the Project Shoal site underground nuclear test. 


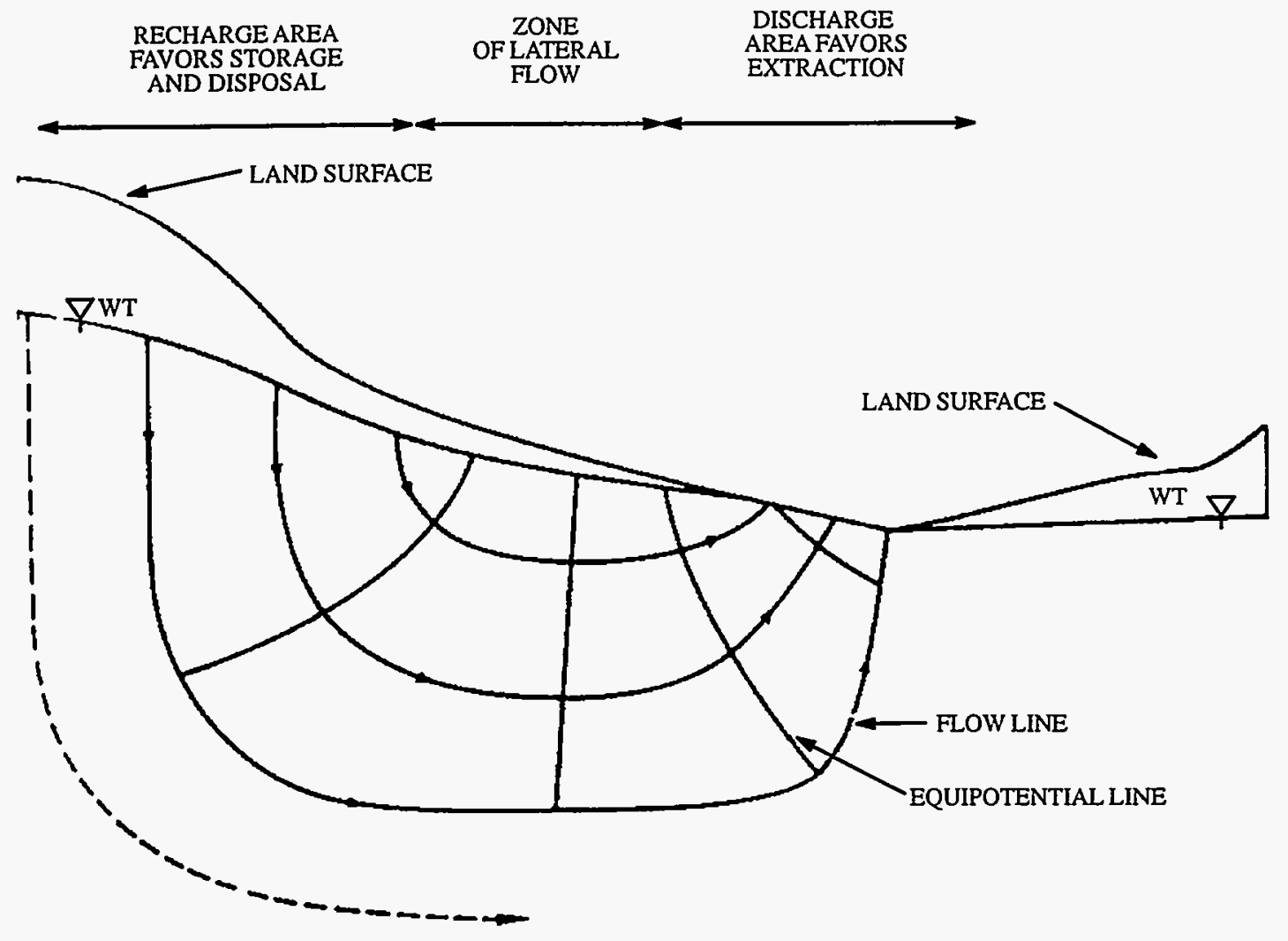

Figure 2. Idealized groundwater flow in a local system with notes for suggested land use, as presented by Maxey (1967).

at the margin of the playa (at the "hinge line") to a central playa, where the water evaporates and infiltrates as saturated brine. The dense pore fluid in the central playa sinks in the underlying fresh groundwater and a depression in the water table results, inducing additional flow to the playa. Density differences between the fresh water recharging from the mountains and the residual evaporating fluid can be large enough to drive free convection of the dense brine beneath a fresh water lens. A counter flow then develops, with low-salinity water flowing toward the playa and underlying brine flowing toward the basin margin. The presence of refluxing brine can effectively block flow from the range into the deeper portions of the adjacent valleys, thereby reducing flow path length and travel times to discharge areas.

Our study of the Shoal site is directed toward refining the conceptual model of contaminant transport from the nuclear cavity through the groundwater system to the accessible environment. This is focused on one basic issue: the nature of flow from the recharge area in the range to the discharge areas on either side. 


\section{APPROACH}

Geologic and hydrologic investigations of the Shoal area were conducted as part of the support for the nuclear test (Nevada Bureau of Mines et al., 1965). This included a modest drilling and testing program to establish general hydrologic conditions. Hydrochemical studies were included, but wide variations in analyses of samples collected from the same location at different times and large charge-balance errors for some of the analyses indicate analytical quality problems. The current work involved obtaining additional information about the natural system using the springs and existing wells. Water samples were collected in 1991, 1992, and 1993 from five wells and three springs around the Sand Springs Range (see Figure 1). Existing pumps were used to collect the samples at HS-1, $\mathrm{H}-3$, and the Wightman well after appropriate purging. A temporary pump was lowered into H-2 for sampling and Bucky O'Neil Well is a flowing well which required no special equipment. Samples from both Sand Spring and Rock Spring had to be collected from surface catchment features which, though actively flowing, had an unknown water residence time. At the time of sampling, Smith-James Spring was a diffuse, low-flow seep which was sampled by damming the resultant small stream. The samples were analyzed for major anions and cations, the stable isotopes of oxygen and hydrogen, tritium, and in some cases carbon-13 and carbon-14. Hydrochemical logging of temperature, electrical conductivity, and $\mathrm{pH}$ was conducted in the $\mathrm{H}-2$ borehole, and additional discrete bailed samples were collected based on the logging results.

\section{RESULTS}

Major ion analyses reveal three hydrochemical facies in the Shoal area samples (Table 1) (Figure 3). The lowest salinity water (electrical conductivities (EC) values of $400-800 \mu \mathrm{S} / \mathrm{cm}$ ) has a mixed cation- $\mathrm{HCO}_{3}$ signature and is found in the one high-altitude spring (Smith-James Spring) and the one sample from the east side of the Sand Springs Range in Fairview Valley (well HS-1). A mixed cation-Cl water with higher dissolved solids ( $\mathrm{EC}$ of $2000-4000 \mu \mathrm{S} / \mathrm{cm}$ ) is found in samples collected from wells on the fans leading westward from the range (H-3 and Wightman Well). A brackish (EC of 13,000 to $30,000 \mu \mathrm{S} / \mathrm{cm}$,) Na-Cl water is found closer to and at the discharge areas on the west side.

These general groupings are also found in the stable and radioactive isotopes. The eastern water from HS-1 is isotopically light ( $\delta \mathrm{D}=-123 \%$ ) (Figure 4 ) and contains little carbon-14 (PMC $=8.3$ ). The western fan water is isotopically heavier $(\delta \mathrm{D}=-121$ to $-111 \%$ ) and contains more carbon-14 ( $\mathrm{PMC}=0.28$ to 0.44$)$. Water in the discharge area is isotopically enriched $(\delta \mathrm{D}=-91$ to $-76 \%$ ), but contains variable, low carbon-14 (PMC of 0.02 to 0.145 ). Only one sample contained tritium above the detection limit of $10 \mathrm{pCi} / 1$; the Smith-James Spring water contained $51 \pm 10 \mathrm{pCi} / \mathrm{l}$.

Chemical logging revealed a distinctly stratified water column at well $\mathrm{H}-2$ (Figure 5). The stratification appears to be based on chemically driven density differences, with the most saline water $(\mathrm{EC}=55,000 \mu \mathrm{S} / \mathrm{cm})$ found at the bottom of the well $(210-226 \mathrm{~m})$, overlain by slightly less saline water $(E C=50,000 \mu \mathrm{S} / \mathrm{cm}$ ) from 195 to $145 \mathrm{~m}$, where a sharp drop in conductivity marks the upper zone with an EC of about $10,000 \mu \mathrm{S} / \mathrm{cm}$ from $145 \mathrm{~m}$ to the water surface at $33.5 \mathrm{~m}$. The $\mathrm{pH}$ log shows the same three layers and more clearly demarks a transition zone between 202.7 and 210.3 $\mathrm{m}$. Perturbations in the temperature log occur at both of the transitions between the three zones. 
Table 1. Chemical Analyses of Water Samples Collected in the Area of the Sand Springs Range. All units are mg/l unless noted otherwise.

\begin{tabular}{|c|c|c|c|c|c|c|c|c|c|c|c|c|c|c|c|c|c|c|c|}
\hline Well & Depth (m) & Date & $\begin{array}{c}\mathrm{T} \\
\left({ }^{\circ} \mathrm{C}\right)\end{array}$ & $\begin{array}{l}\mathrm{pH}^{\mathrm{l}} \\
\text { (S.U.) }\end{array}$ & $\begin{array}{c}\mathrm{EC}^{\mathrm{l}} \\
(\mu \mathrm{S} / \mathrm{cm})\end{array}$ & $\mathrm{SiO}_{2}$ & $\overline{\mathrm{Ca}}$ & $\mathrm{Mg}$ & $\mathrm{Na}$ & $\bar{K}$ & $\mathrm{Cl}$ & $\mathrm{SO}_{4}$ & $\mathrm{HCO}_{3}{ }^{1}$ & $\mathrm{CO}_{3}$ & $\overline{\mathrm{NO}_{3}}$ & $\overline{\mathrm{Br}}$ & $\begin{array}{l}\delta^{18} \mathrm{O} \\
(\%)\end{array}$ & $\begin{array}{l}\delta \mathrm{D} \\
(\%)\end{array}$ & $\begin{array}{c}{ }^{3} \mathrm{H} \\
(\mathrm{pCi} / \mathrm{L})\end{array}$ \\
\hline Bucky O'Neil & & 12-Jun-91 & 20 & $8.81 / 8.68$ & $\begin{array}{l}14,700 / \\
14,000\end{array}$ & 35.3 & 6.06 & 1.59 & 3260 & 103 & 3810 & 1140 & $660 / 547$ & 52.5 & 0.04 & 18 & -9.1 & -86 & $<10$ \\
\hline Bucky O'Neil & & 15-Jun-93 & & 8.7 & 13,900 & 37 & 6.05 & 1.92 & 3230 & 106 & 4020 & 1130 & 574 & 43.8 & $<0.04$ & & -8.7 & -86 & \\
\hline Wightman well & & 12-Jun-91 & 28 & $7.58 / 8.04$ & $\begin{array}{l}1995 / \\
1960\end{array}$ & 48.5 & 135 & 49.8 & 161 & 12.6 & 501 & 103 & $100 / 98.3$ & & 9.66 & & -14.5 & -118 & $<10$ \\
\hline $\begin{array}{l}\text { Wightman } \\
\text { Well }\end{array}$ & & 26-Aug-92 & & 7.97 & 1630 & 47.1 & 106 & 40.8 & 138 & 11.5 & 380 & 80 & 96.1 & & 9.83 & 1.6 & -14.8 & -121 & $<10$ \\
\hline Rock Spring & & 12-Jun-91 & 18.5 & $8.22 / 8.28$ & $\begin{array}{l}4920 / \\
5230\end{array}$ & 85.0 & 11.7 & 2.01 & 1070 & 68.2 & 1350 & 246 & $410 / 398$ & 7.6 & 0.09 & 3.5 & -13.9 & -121 & $<10$ \\
\hline Sand Spring & & 13-Jun-91 & 24.5 & $9.25 / 9.21$ & $\begin{array}{l}4050 / \\
4050\end{array}$ & 33.4 & 2.52 & 0.54 & 876 & 39.7 & 885 & 253 & $500 / 363$ & 74.1 & $<0.04$ & 2.7 & -11.6 & -107 & $<10$ \\
\hline $\begin{array}{l}\text { Smith-James } \\
\text { Spring }\end{array}$ & & 13-Jun-91 & 22 & $8.35 / 8.31$ & $800 / 749$ & 33.9 & 72.2 & 10.4 & 76.4 & 3.29 & 52.0 & 65.2 & $290 / 311$ & 1.38 & 0.13 & 0.25 & -14.1 & -106 & $51 \pm 10$ \\
\hline HS-1 & & 30-Mar-92 & & $7.72 / 8.14$ & $428 / 438$ & 68.7 & 31.5 & 5.37 & 47.2 & 7.11 & 29.3 & 51.5 & $110 / 140$ & & 3.99 & $<0.1$ & -16.3 & -123 & $<10$ \\
\hline $\mathrm{H}-3$ & & 26-Aug-92 & & 7.76 & 4830 & 6.5 & 197 & 183 & 457 & 15.8 & 1400 & 148 & 99.4 & & 0.80 & 4.1 & -12.8 & -111 & $<10$ \\
\hline $\mathrm{H}-2$ & 80.8 & 18-Dec-91 & & 9.68 & 19,100 & $<1$ & 6.39 & 22.9 & 4370 & 40.6 & 5640 & 809 & 141 & 157 & $<0.04$ & 16.8 & -7.6 & -76 & $<10$ \\
\hline $\mathrm{H}-2$ & $\begin{array}{c}\text { pumped, } \\
91.4\end{array}$ & 25-Aug-92 & & 7.8 & 42,100 & 33.0 & 133 & 219 & 10,800 & 63.1 & 14,900 & 3320 & 1340 & & 0.04 & 48.5 & -7.9 & -85 & $<10$ \\
\hline $\mathrm{H}-2$ & 80.8 & 15-Jun-93 & & 9.15 & 17,300 & 2.5 & 13.3 & 86.6 & 3850 & 43.7 & 5380 & 1200 & 82.7 & 51.5 & $<0.04$ & & -7.1 & -76 & \\
\hline $\mathrm{H}-2$ & 160 & 15-Jun-93 & & 9.01 & 44,800 & 5.1 & 3.6 & 243 & 11,500 & 68.2 & 16,300 & 2980 & 1150 & 329 & $<0.04$ & & -7.8 & -82 & \\
\hline $\mathrm{H}-2$ & 205 & 15-Jun-93 & & 9.09 & 45,900 & 3.5 & 3.28 & 205 & 12,000 & 68.2 & 16,600 & 3290 & 957 & 351 & $<0.04$ & & -8.2 & -84 & \\
\hline $\mathrm{H}-2$ & 219.5 & 15-Jun-93 & & 9.06 & 48,300 & 3.8 & 5.51 & 218 & 12,500 & 73.4 & 17,700 & 3610 & 605 & 253 & $<0.04$ & & -9.2 & -91 & \\
\hline
\end{tabular}

\footnotetext{
${ }^{1}$ First number is a measurement in the field at the time of sample collection. Second number is a laboratory measurement. If there is only one number, it is a laboratory measurement.
} 


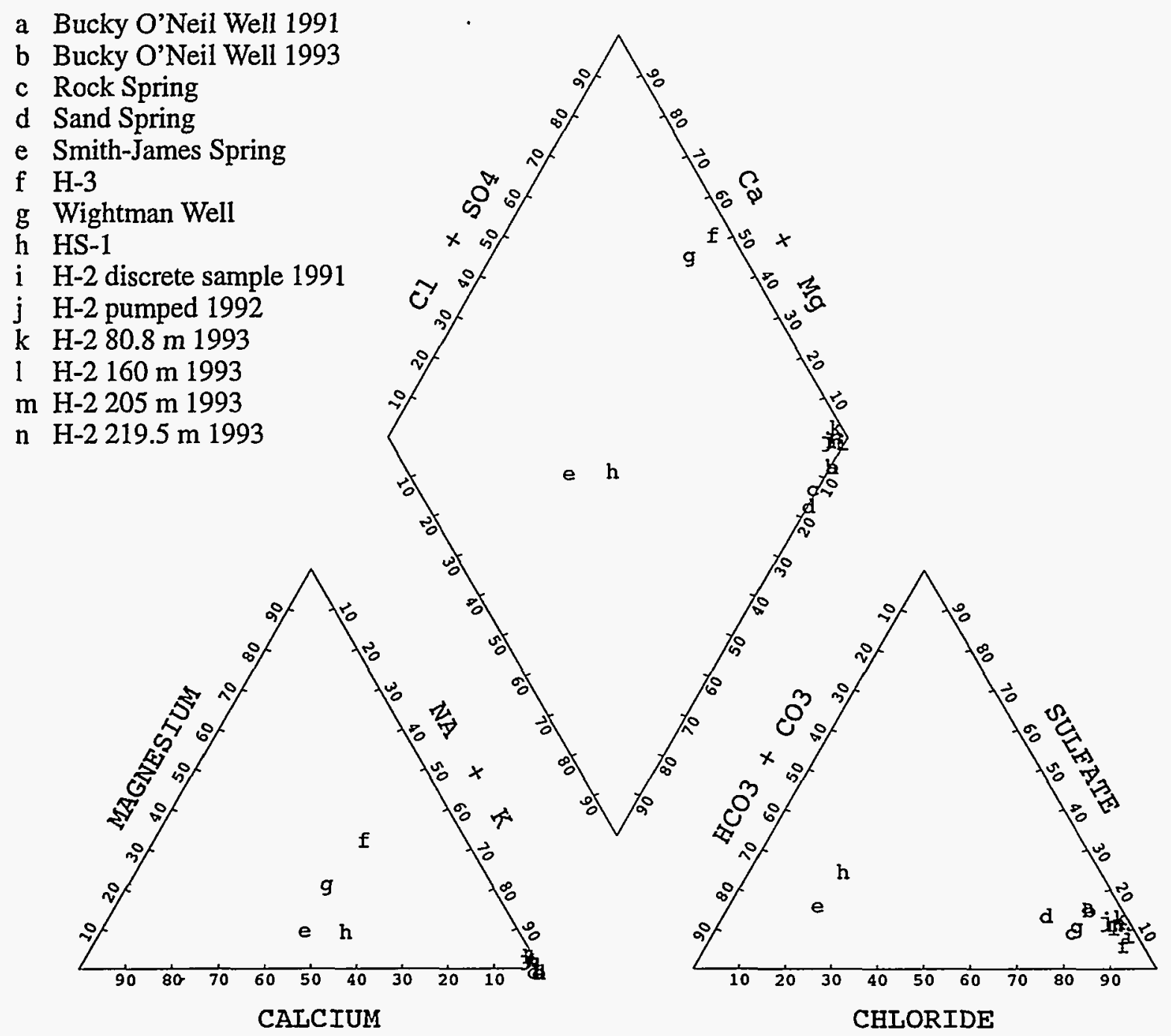

Figure 3. Piper diagram demonstrating the three hydrochemical facies in the samples collected for this study. The mixed cation- $\mathrm{HCO}_{3}$ water from Smith-James Spring and $\mathrm{HS}-1$ has the lowest salinity $(\mathrm{EC}=400-800 \mu \mathrm{S} / \mathrm{cm})$, the mixed cation- $\mathrm{Cl}$ water from $\mathrm{H}-3$ and Wightman Well has a moderate salinity $(\mathrm{EC}=2000-4000 \mu \mathrm{S} / \mathrm{cm})$, while the $\mathrm{Na}-\mathrm{Cl}$ water is brackish $(E C=13,000-30,000 \mu \mathrm{S} / \mathrm{cm})$. 


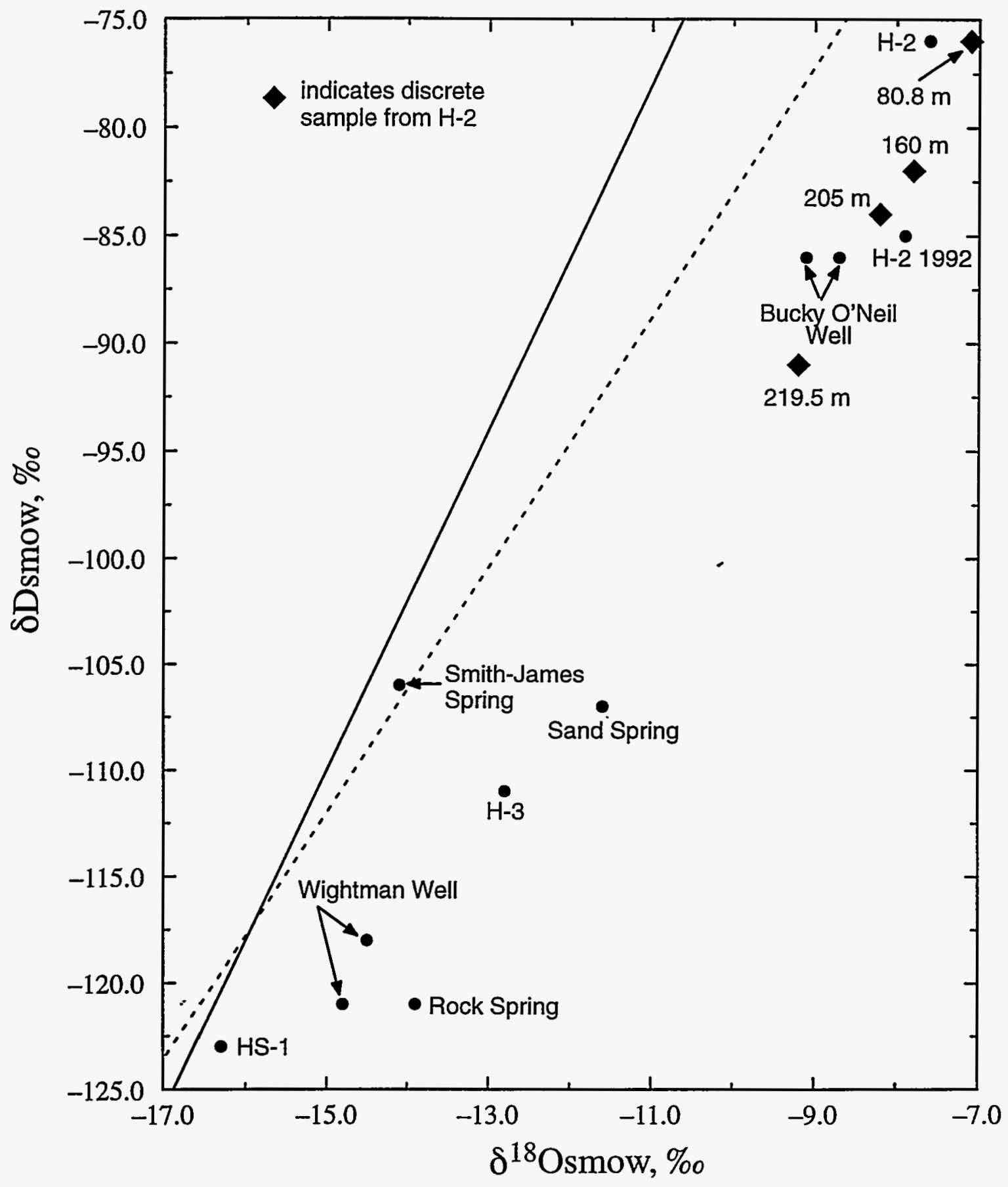

Figure 4. Stable isotope composition of samples collected for this study. The solid line is the global meteoric water line $\left(\delta \mathrm{D}=8 \delta^{18} \mathrm{O}+10\right)$ and the dashed line is a local meteoric - water line $\left(\delta \mathrm{D}=5.8 \delta^{18} \mathrm{O}-25\right)$ as defined by Jacobson et al. (1983). The samples follow

- a trend roughly paralleling the local meteoric water line, but displaced to the right, as is commonly observed in groundwater in semi-arid to arid regions. 


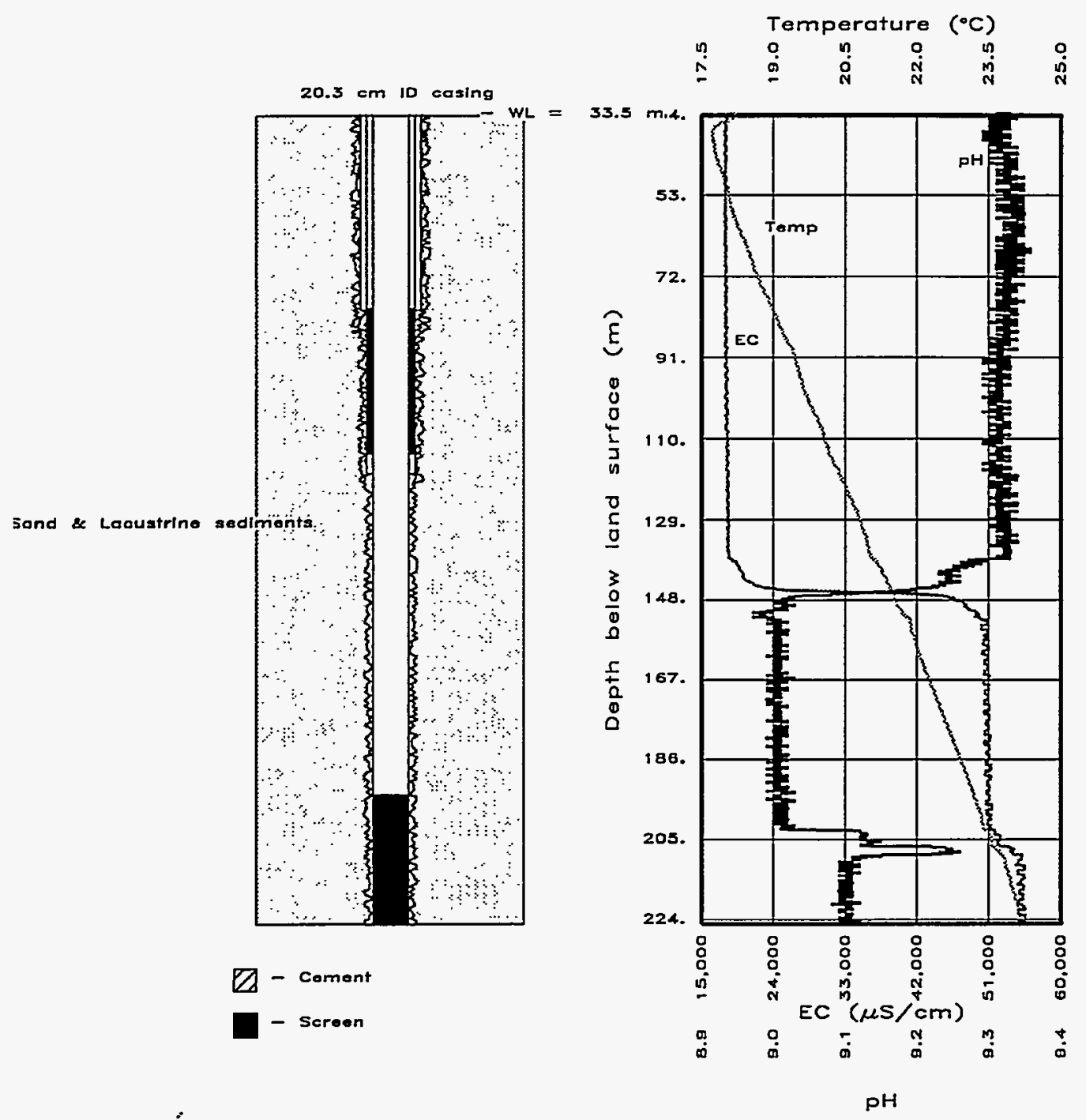

Figure 5. Temperature, conductivity, and $\mathrm{pH}$ logs from well $\mathrm{H}-2$, run on June 15,1993 . Three zones of water are obvious, separated by a sharp contact near $146 \mathrm{~m}$ below land surface and another transition from 195 to $210 \mathrm{~m}$. Small perturbations in the temperature log suggest water flow in the well in the zones around $140 \mathrm{~m}, 153 \mathrm{~m}$, and $203-207 \mathrm{~m}$. 


\section{CONCEPTUAL MODEL OF THE GROUNDWATER FLOW SYSTEM AND MODEL OF CHEMICAL EVOLUTION}

A reasonable model of groundwater flow in the Shoal area begins with recharge occurring from precipitation on the Sand Springs Range and other nearby highland areas. The elevation of the Sand Springs Range ( 1707 to $2073 \mathrm{~m}$ ) is not high enough to be considered a major regional recharge area; thus, groundwater recharge to the adjacent valleys may be controlled by other bounding mountain ranges (particularly the higher elevation Clan Alpine Mountains and Stillwater Range). Local recharge should infiltrate rapidly through the thin soil cover and enter the groundwater system within the fractured granite of the Sand Springs Range. A minor amount of discharge occurs at high-altitude seeps and springs where local hydrologic barriers occur. The majority of groundwater moves hydrologically downgradient (presumed to roughly follow topography) then laterally out to the adjacent valleys. Groundwater in some parts of the range, notably the area east of the Cocoon Mountains, will move through a sequence of metamorphosed sedimentary rocks. Groundwater may encounter localized occurrences of volcanic rocks, either overlying the granite body and metamorphic rocks, or occurring as dikes cutting these rocks. Continuing along the flow path, the water enters alluvial deposits. On the west side of the Sand Springs Range, these alluvial deposits are relatively thin and include Pleistocene sediments deposited by Lake Lahontan. The regional discharge area at the salt pans of Fourmile Flat is relatively close to the Sand Springs Range. Salt has been mined from Fourmile Flat since 1863 (Papke, 1976). On the other side of the range, groundwater in Fairview Valley travels much farther, turning northward to eventually reach natural discharge areas in Dixie Valley (Cohen and Everett, 1963). In addition, the much thicker alluvial section in Fairview Valley (up to $1525 \mathrm{~m}$ of sediment; Nevada Bureau of Mines et al., 1965) suggests the likelihood of multiple, layered flow systems.

The flow model can be represented as a chemical evolutionary path and traced using stable isotopes. The recharging rainwater will bring small amounts of dissolved ions with it into the groundwater system, derived from atmospheric dust $\mathrm{Na}$ and $\mathrm{Cl}$ could both be common in dust of the area due to the location of the salt flats in the predominant wind direction). Movement through the plant-root zone will acidify the water with dissolved $\mathrm{CO}_{2}$. While in the granite, the primary reaction should be silicate hydrolysis, with the destruction of alkali feldspar and creation of a clay such as kaolinite. This will add $\mathrm{Na}$ and/or $\mathrm{K}$ and $\mathrm{SiO}_{2}$ to the groundwater. Any groundwater moving through the metamorphic rocks at the southern end of the range may dissolve the recrystallized dolomitic limestone, adding $\mathrm{Ca}$ and $\mathrm{Mg}$ to solution. Dissolution of andesine and formation of montmorillinite should be common, adding $\mathrm{Ca}$ and $\mathrm{Na}$ to solution, when groundwater encounters volcanic units. In the Fourmile Flat basin, there may be dissolution of sedimentary material and precipitation of carbonate minerals. The final step in geochemical evolution in that basin is the formation of gypsum- and then halite-saturated brines which redeposit their salts during evaporative discharge.

Stable isotope compositions will be established for the groundwater during the recharge process. Water recharged at higher elevations will be depleted in the heavy isotopes of hydrogen and oxygen. Similarly, water recharged under cooler conditions in the past will also have a depleted character. In the absence of geothermal systems or mixing, the recharge isotope signature will 
remain with the groundwater until evaporation occurs near the discharge area. Evaporation will enrich the water in heavy isotopes.

\section{FITTING THE CONCEPTUAL MODEL TO THE SITE DATA}

The ideal evolutionary path must be approximated with the available data. Smith-James Spring is the only sample from the Sand Springs Range. A western flow path can be assembled along a transect of H-3, H-2, and Bucky O'Neil Well, with Wightman Well located on a roughly parallel transect in approximately the H-3 position. Bucky O'Neil, Sand Spring, and Rock Spring are all natural discharge points along the edge of Fourmile Flat, on similar flow paths from different parts of the surrounding highlands. The sample from HS-1 is the only one to represent flow into Fairview Valley.

To determine if the sparse data are representative, they can be evaluated by placing them in a regional context with published analyses (Figure 6). The published analyses were performed as part of Shoal site investigations (Nevada Bureau of Mines et al., 1965), and there are large charge-balance errors for some of them. Only analyses with error less than $15 \%$ are shown on Figure 6 . In addition, records indicate that most of the wells designated as "Range" in the figure were contaminated by drilling water from HS-1. Unfortunately, all of the wells drilled in the range for the Shoal Project were abandoned and are no longer accessible. The sample from well PM-1 is believed to be most representative of in situ conditions close to the test site. Despite these problems, the additional data confirm the general difference between groundwater on the east and west sides of the Sand Springs Range.

The significant chemical and isotopic differences between water on the east and west sides of the Sand Springs Range suggest that the model described above is incomplete. Sediments in the western valley are generally finer grained and of lacustrine origin as compared to the coarser, alluvial deposits to the east, consistent with more water-rock interaction and higher salinities on the west side of the range. However, sedimentologic differences cannot account for all of the hydrochemical distinction because H-3 exhibits the higher salinity, Cl-facies water typical of the west side, but groundwater at that point still occurs in the granite rock comprising the range itself.

In addition, the unusually high salinity of the water sampled from $\mathrm{H}-2$ (EC values from 17,000 to $50,000 \mu \mathrm{S}$ ) is anomalous compared to its position on the flow path because $\mathrm{H}-2$ is more saline than water sampled downgradient at the discharge zone at Bucky O'Neil Well. During the drilling of well H-2, water levels increased $5.2 \mathrm{~m}$ as the hole was deepened (Nevada Bureau of Mines et al., 1965). The well is open to $228.6 \mathrm{~m}$ below land surface, with a slotted interval from 194 to $228.6 \mathrm{~m}$ and another slotted interval from 79.6 to $113.4 \mathrm{~m}$ that occurs within an apparently unslotted outer casing string (which ends at $120.4 \mathrm{~m}$ ). There is poor casing integrity due to corrosion by salty water, evidenced by chunks of rusty casing on top of the sample bailer. Thus, water sampled at the top of the well may actually be representative of groundwater in deeper sediments, providing a window into the basin flow system. 

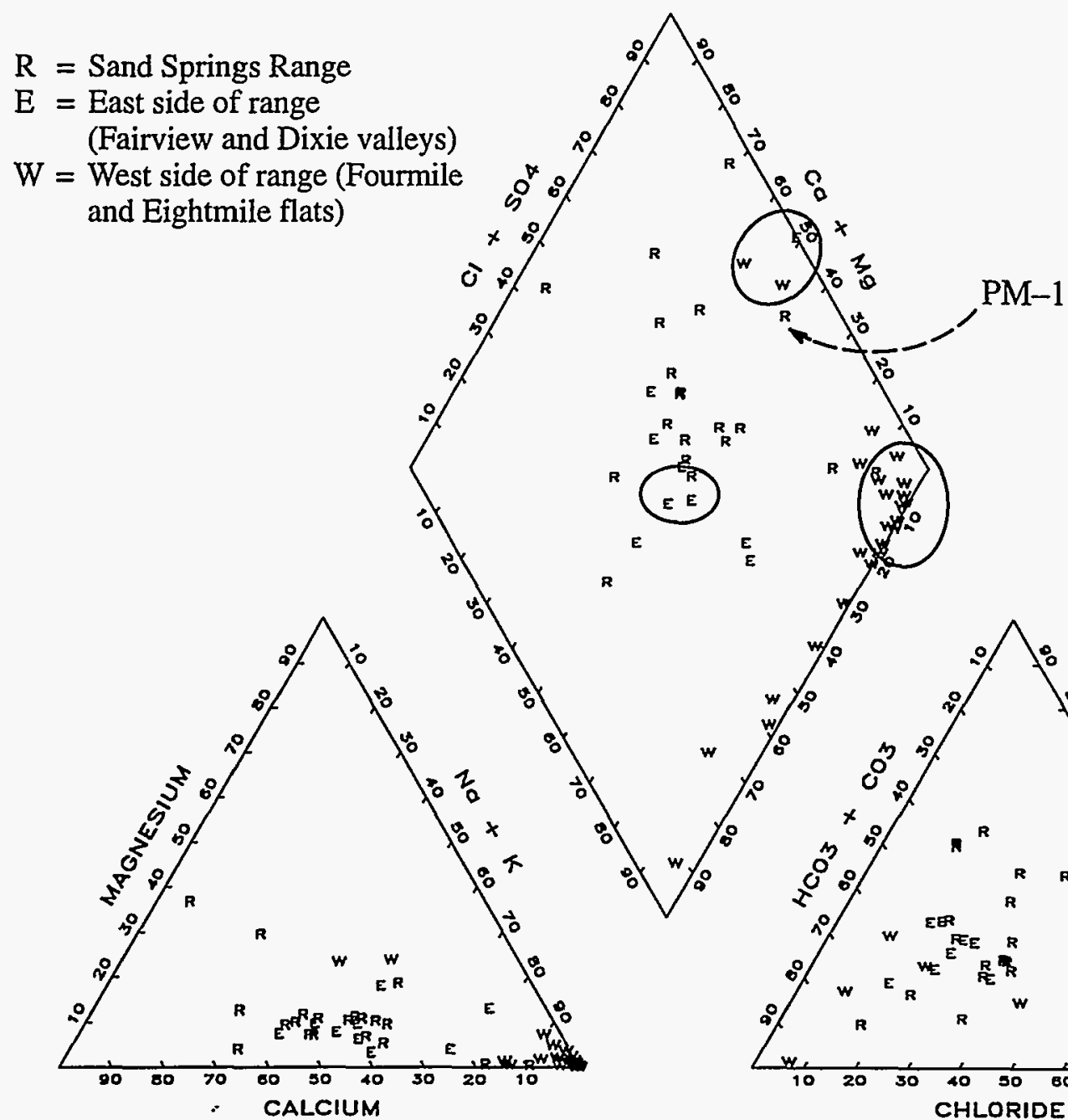$$
E_{R}^{R} R_{R}^{R}
$$
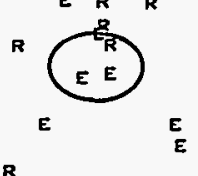

$\stackrel{E}{E}$
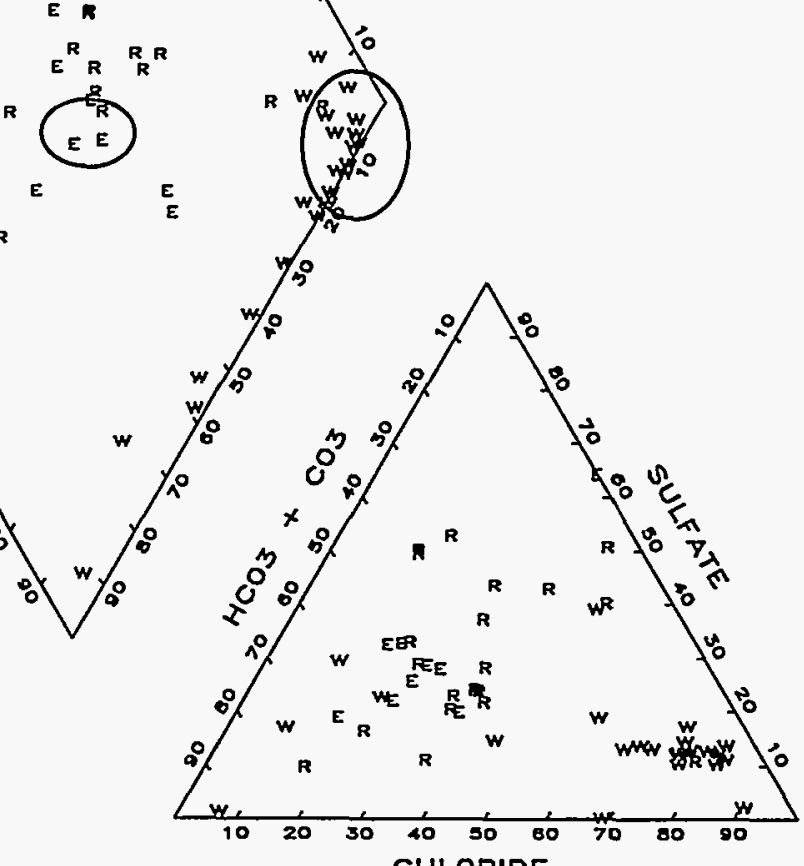

Figure 6. Piper diagram of chemical analyses of water samples collected in the study region, published during investigation of the Shoal site prior to the nuclear test (Nevada Bureau of Mines et al., 1965). The circled areas correspond to the hydrochemical facies identified in Figure 3. Only analyses with charge-balance errors less than 15\% are shown. Many of the samples designated as being from the range are suspected of being contaminated by drilling water supplied by HS-1. The sample from PM-1 is believed to be most representative of groundwater in the vicinity of the Shoal test. On the whole, the regional data support a chemical difference between groundwater on the east and west sides of the Sand Springs Range. 


\section{THE REFLUXING BRINE MODEL}

Duffy and Al-Hassan (1988) presented a model for closed-basin circulation that coupled flow and salinity by including both pressure and density forces in Darcy's law. In their model, there is mass transfer of solutes by advection from recharge zones in the highlands to a discharge zone in a central playa. The model allows for the possibility of free convection caused by density differences between the recharging fluid and residual evaporating fluid. They define a Rayleigh number $\left(R_{a}\right)$, which relates the buoyancy forces to other forces tending to resist flow, and use this number to evaluate whether or not free convection will occur. Though the exact threshold value for free convection was not determined, Duffy and Al-Hassan (1988) believe it is on the order of $\mathrm{R}_{\mathrm{a}}$ values of 400 to 600 . Pilot Valley, in northwestern Utah, was used for numerical simulations to evaluate the effects of recharge and discharge conditions, relying primarily on topographic and climatic information. Under some conditions, the salt nose was found to penetrate the margin of the basin with the fresh water zone confined to a thin wedge. They note that this would be the case in a very arid basin bounded by low elevation mountains with corresponding low precipitation.

The Rayleigh number defined by Duffy and Al-Hassan (1988) was calculated for the Fourmile Flat basin to evaluate the potential for reflux brines to migrate toward the Sand Springs Range. The equation and variables are as follows:

$$
R_{a}=\frac{\left[\frac{K \Delta \varrho g / \mu}{\bar{\varepsilon}}\right]}{\left[\frac{\alpha_{T}}{L}\right]\left[\frac{L}{D}\right]}
$$

where $\mathrm{K}=$ mean permeability

$\Delta \varrho=$ density contrast between recharge and discharge fluids

$\mathrm{g}=$ gravitational constant

$\mu=$ dynamic viscosity

$\bar{\varepsilon} \quad=$ mean recharge rate

$\alpha_{\mathrm{T}}=$ transverse dispersivity

$\mathrm{L}=$ horizontal extent of basin (recharge zone to central discharge zone)

$\mathrm{D}=$ thickness of aquifer

The mean permeability, $6.4 \times 10^{-8} \mathrm{~cm}^{2}$, was obtained from pumping test data at $\mathrm{H}-2$ (Nevada Bureau of Mines et al., 1965). The density contrast $\left(0.2 \mathrm{~g} / \mathrm{cm}^{3)}\right.$ is that between a halite-saturated brine $\left(1.2 \mathrm{~g} / \mathrm{cm}^{3}\right)$, found in the central part of Fourmile Flat, and fresh water $\left(1.0 \mathrm{~g} / \mathrm{cm}^{3}\right)$. The gravitational constant is $978 \mathrm{~cm} / \mathrm{s}^{2}$ and the dynamic viscosity is $0.01124 \mathrm{~g} / \mathrm{cm} \cdot \mathrm{s}$. The mean recharge rate is $2.14 \mathrm{~cm} / \mathrm{yr}$, or $6.77 \times 10^{-8} \mathrm{~cm} / \mathrm{s}$ and assumes $7 \%$ recharge of the estimated $30.5 \mathrm{~cm} / \mathrm{yr}$ precipitation that falls on the Sand Springs Range, per Maxey and Eakin (1949). The transverse dispersivity was varied between $5-500 \mathrm{~cm}$. The horizontal extent of the basin is $950,000 \mathrm{~cm}$. The thickness of the porous medium is that of the central basin, $40,000-76,000 \mathrm{~cm}$, based on gravity and aeromagnetic studies (Nevada Bureau of Mines et al., 1965). 
In the Fourmile Flat case, the dimensionless $R_{a}$ value is of the order of $10^{6}$ to $10^{8}$, depending on the value of transverse dispersivity used. Compared to the threshold suggested by Duffy and Al-Hassan (1978), free convection is expected in the basin. The situation in Fairview Valley is much different because the primary discharge area is located far to the north in Dixie Valley. The small playa at Labou Flat in Fairview Valley is a remnant lakebed that does not serve an active discharge function, evidenced by the lack of springs around its margin. Thus, there is no build-up of salinity in the basin directly east of the Sand Springs Range.

\section{CHEMICAL AND LOGGING EVIDENCE FOR REFLUX WATER}

The chemical log from H-2 (Figure 5) is consistent with the presence of refluxing water between the Sand Springs Range and Fourmile Flat. The apparently anomalous salinity at H-2 is a function of the well accessing deeper, saline water as compared to H-3 and Bucky O'Neil Well (Figure 7). The density stratification in the well may be reflective of stratification in the natural system, though the well itself and its completion have perturbed the in situ conditions. The temperature log has only a few short intervals that suggest significant flow into or out of the borehole; these are seen as step temperature changes near each of the conductivity breaks. One of these, around $204 \mathrm{~m}$, coincides with slots in the casing, while the others at about 140 and $152 \mathrm{~m}$ may indicate breaks in the casing (probably caused by corrosion). If the remainder of the casing is intact, then the lower zone with EC values over $40,000 \mu \mathrm{S} / \mathrm{cm}$ is probably representative of water entering through the slots between 194 and $228.6 \mathrm{~m}$. The upper zone with $\mathrm{EC}$ values around 17,000 $\mu \mathrm{S} / \mathrm{cm}$

\section{Sand Springs Range}

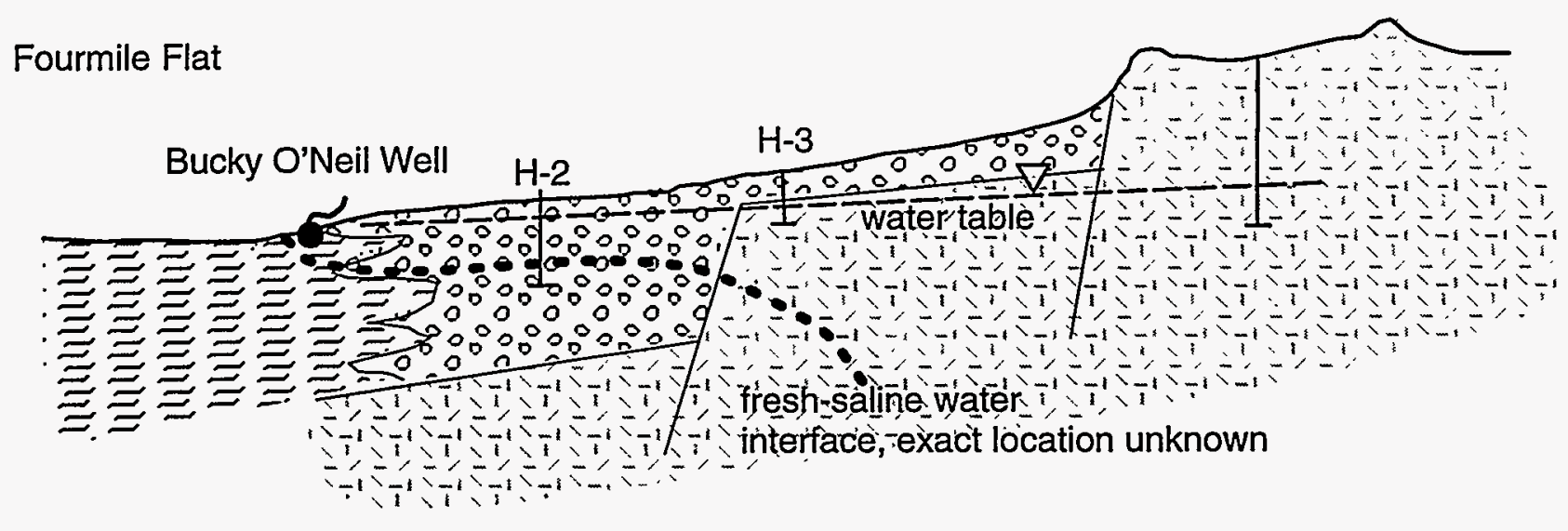

El lake sediments $\quad \because 00$ alluvial fan sediments

Figure 7. Conceptual depiction of reflux brine west of the Sand Springs Range. Data are too - sparse to confirm either the subsurface geology or location of brine fresh water interface. 
represents either water from $140-152 \mathrm{~m}$, or possible water between 80 and $113 \mathrm{~m}$, where there are records of slots in the inner casing string but no record of any access through an outer string ending at $120.4 \mathrm{~m}$. Regardless, water sampled at the top of the $\mathrm{H}-2$ water column is probably not representative of the water table, but rather of water at least $45.7 \mathrm{~m}$ deeper. Groundwater at that depth and below appears to be the product of mixing of refluxing brine with fresher water from the recharge zone.

Approximate lengths of brine incursion were calculated by Duffy and Al-Hassan (1988) for Pilot Valley, but the modeling required for those calculations has not been done yet for Fourmile Flat. However, given the apparent low recharge rates, it is possible that the reflux water may have moved farther to the east than H-2 and may in fact be responsible for the increase in salinity between the range and H-3. Mixing is suggested by a linear relationship in the stable isotopic compositions of all the samples with the exception of Smith-James Spring (Figure 4). The relationship is believed to be due to mixing rather than evaporation because the slope of the line defined by the samples $\left(\delta \mathrm{D}=5.6 \delta^{18} \mathrm{O}-38, \mathrm{n}=14, \mathrm{r}^{2}=0.99\right)$ does not differ substantially from that of the local meteoric water line $\left(\delta \mathrm{D}=5.8 \delta^{18} \mathrm{O}-25, \mathrm{n}=42\right)$ defined by Jacobson et al. (1983) based on precipitation samples from Dixie Valley and other northern Nevada locations. A strong correlation $\left(r^{2}=0.996\right)$ between $\delta D$ and $\mathrm{Cl}$ for HS-1, Wightman Well, H-3, the upper H-2 samples, and Bucky O'Neil Well (Figure 8) suggests that the water itself, as well as its dissolved constituents, is the product of mixing. Differences in the temperature of condensation, caused by climate change tied to glacial cycles, could account for the isotopic differences, but the poor relationship between both corrected and uncorrected carbon-14 ages and $\delta \mathrm{D}$ (Figure 9) and strong relationship between $\delta \mathrm{D}$ and $\mathrm{Cl}$ favor the mixing hypothesis.

The endmembers are represented by HS-1 (a water with no contact to reflux brine) and the upper zone water at $\mathrm{H}-2$ (presumably the part of the reflux body in contact with overlying fresh water). The differences between the chemical and isotopic composition of groundwater on the east and west sides of the Sand Springs Range thus appear to be primarily due to the presence of reflux water on the west and its absence to the east. If HS- 1 and the upper $\mathrm{H}-2$ water are representative of endmembers, then water from the Wightman Well is comprised of about $8 \%$ reflux water, $\mathrm{H}-3$ is about $25 \%$ reflux water, and about $70 \%$ of the water discharging at Bucky O'Neil Well is reflux rather than water originating directly from the Sand Springs Range. Compared to Bucky O'Neil Well, the other springs sampled around Fourmile Flat show much less impact of reflux brine. Rock Spring is actually located at Eightmile Flat, which according to topographic maps drains to Fourmile Flat. A constriction in the Salt Wells basin between Fourmile and Eightmile flats may reflect some subsurface feature (e.g., a basement sill) that inhibits the movement of brine from the salt pans of Fourmile Flat to the west. Sand Spring discharges along the edge of Fourmile Flat and plots close enough to the $\delta \mathrm{D}-\mathrm{Cl}$ mixing line to suggest that it too is the product of reflux water mixing, just not to the degree of Bucky O'Neil Well. This apparent lower reflux component (about 30\% at Sand Spring as compared to $70 \%$ at Bucky O'Neil Well and position on the $\delta \mathrm{D}-\mathrm{Cl}$ plot midway between Smith-James Spring and H-3, may be the result of greater recharge upgradient of Sand Spring, presumably in the large dune field located between the spring and the southern Stillwater Range. 

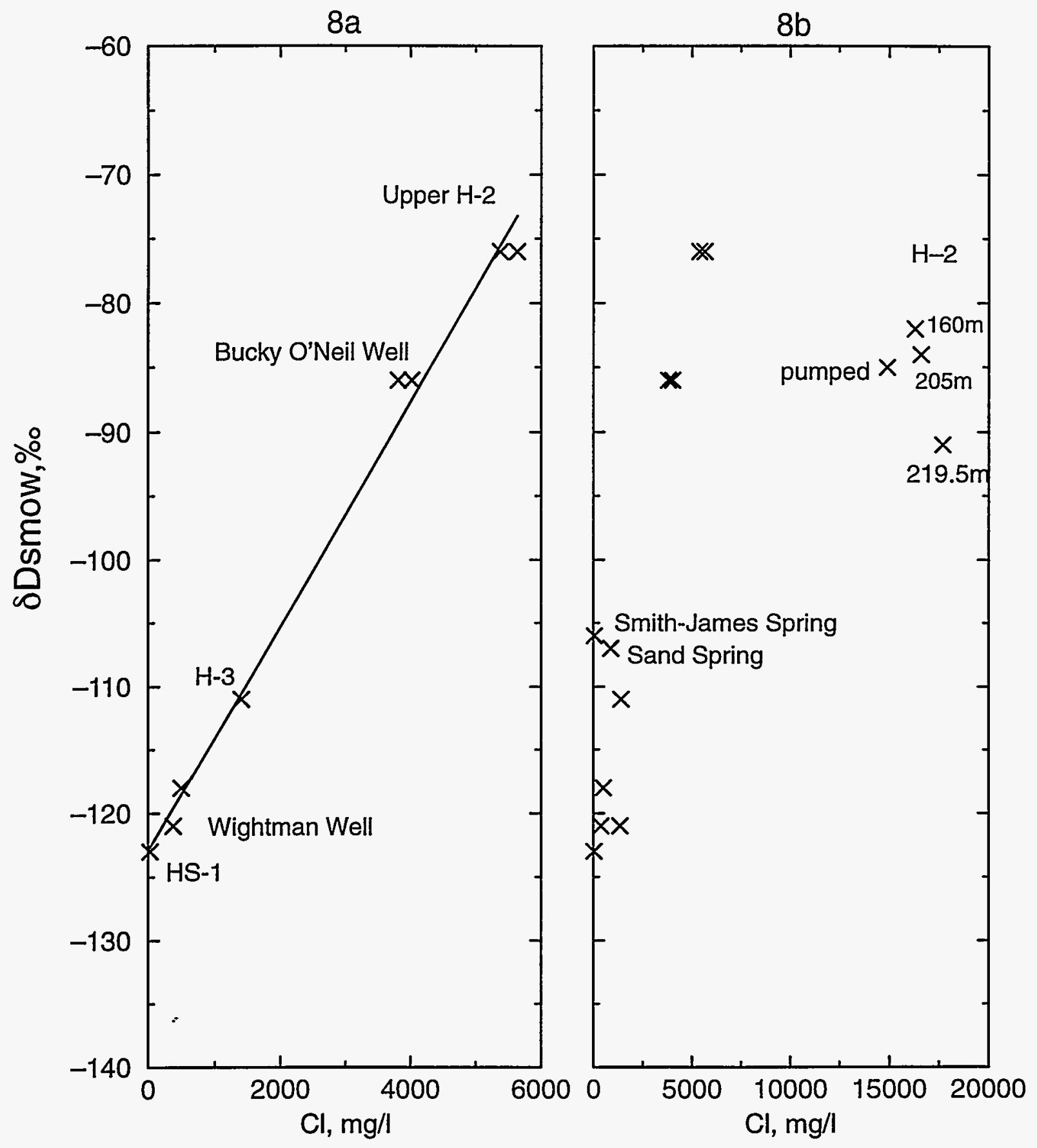

Figure $8 \mathrm{a}$ and $8 \mathrm{~b}$. $\delta \mathrm{D}$ plotted against chloride, with all samples shown on $8 \mathrm{~b}$, and a limited $\mathrm{Cl}$ range shown on 8a. Several springs not on the direct flow path from the Sand Springs Range to Bucky O'Neil Well are also not shown on $8 \mathrm{a}$. The regression on 8 a has a correlation coefficient of 0.996 , and may represent a mixing line between the $\mathrm{H}-2$ and $\mathrm{HS}-1$ endmembers. The higher $\mathrm{Cl}$ samples from $\mathrm{H}-2$ shown on $8 \mathrm{~b}$ define a much different, and inverse, relationship. 


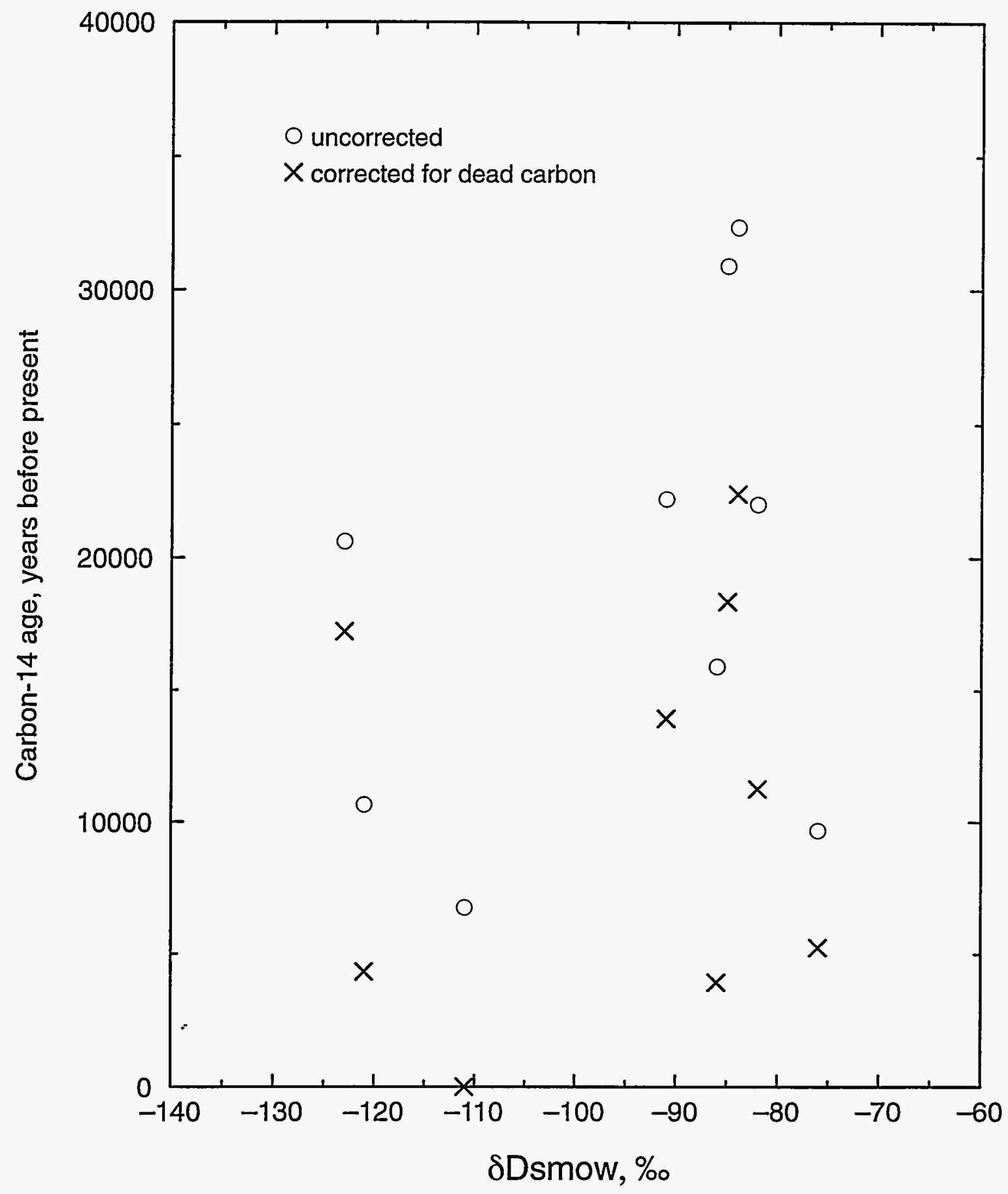

Figure 9. Carbon-14 plotted against $\delta \mathrm{D}$, with uncorrected or "apparent" ages and ages corrected for addition of dead carbon assuming intial carbon-13 values of $-15 \%$ (described in text). No relationship between $\delta \mathrm{D}$ and carbon-14 is evident to suggest that the observed range in stable isotope compositions is primarily controlled by paleoclimate. 


\section{RECHARGE MECHANISMS}

Interpreting HS-1 as a mixing endmember implies that water recharging through the range has had a fairly constant isotopic composition, and thus recharge temperature, for a long and stable period covering emplacement of water throughout the flow path from the range to Bucky O'Neil Well. Additionally, the difference of Smith-James Spring suggests that current recharge is substantially more enriched, implying that the well waters were all recharged under cooler conditions. The carbon-14 data lead to apparent uncorrected residence times between 6750 years before present (ybp) (H-3) and 20,600 ybp (HS-1) (Table 2). The $\delta^{13} \mathrm{C}$ values are all enriched compared to expected recharge values in equilibration with semi-arid plants, suggesting dilution of the water's carbon content by inorganic, dead carbon. Correcting for this apparent dilution using the following relation:

$$
a_{c}^{14}==\frac{a_{m}^{14}\left(\delta^{13} C_{\text {plants }}\right)}{\delta^{13} C_{\text {sample }}}
$$

where $a_{c}^{14}$ is the corrected activity and $a_{m}^{14}$ is the measured activity, and using $-15 \%$ ofor $\delta^{13} C_{\text {plants }}$, gives a range in ages of essentially modern at $\mathrm{H}-3$ to $17,200 \mathrm{ybp}$ at $\mathrm{HS}-1$ (Table 2). It is not reasonable that recharge conditions have been stable over this time period because this spans the previous pluvial period and subsequent interglacial. Past changes in the hydrologic balance of the region were large in magnitude and relatively rapid, presumably resulting from changes in the position of the jet stream (Benson and Thompson, 1987). Such climatic changes are likely to have caused variations in the isotopic composition of recharge.

Table 2. Carbon Isotope Analyses for Samples Collected in the Area of the Sand Springs Range. Counting errors were not available for the discrete $\mathrm{H}-2$ samples analyzed by Lawrence Livermore National Laboratory.

\begin{tabular}{lcccll}
\hline \hline \multicolumn{1}{c}{ Well } & $\begin{array}{c}\text { Carbon-13 } \\
\% o\end{array}$ & $\begin{array}{c}\text { Percent } \\
\text { Modern Carbon }\end{array}$ & $\begin{array}{c}+/- \\
\text { error }\end{array}$ & $\begin{array}{c}\text { Apparent age } \\
\text { (YBP) }\end{array}$ & $\begin{array}{c}\text { Corrected } \\
\text { Age (YBP) }\end{array}$ \\
\hline Bucky O'Neil Well & -3.5 & 14.5 & 0.3 & 15,800 to 16,100 & 3800 to 4100 \\
Wightman Well & -7.0 & 27.7 & 1.6 & 10,200 to 11,100 & 3850 to 4800 \\
HS-1 & -9.9 & 8.3 & 0.9 & 19,700 to 21,500 & 16,300 to 18,100 \\
H-3 & -3.3 & 44.0 & 0.8 & 6600 to 6900 & -5900 to -5600 \\
H-2 $80.8 \mathrm{~m}$ & -8.8 & 31 & & 9680 & 5270 \\
H-2 $160 \mathrm{~m}$ & -4.1 & 7 & & 22,000 & 11,300 \\
H-2 205 m & -4.5 & 2 & & 32,300 & 22,400 \\
H-2 219.5 m & -5.5 & 6.8 & & 22,200 & 13,900 \\
H-2 pumped & -3.3 & 2.4 & 0.3 & 31,900 to 29,900 & 17,300 to 19,400 \\
\hline \hline
\end{tabular}

*corrected using $a_{c}^{14}=\frac{a_{m}^{14}\left(\delta^{13} C_{\text {planss }}\right)}{\delta^{13} C_{\text {sample }}}$, where $\delta^{13} \mathrm{C}_{\text {plants }}=-15 \%$ for semi-arid species. 
Comparing the stable isotopic compositions of the well samples with the composition of samples collected from springs and streams in the Stillwater Range (University of Nevada, 1980) (Figure 10) reveals that most of the Stillwater samples have isotopic compositions between those of HS-1 and H-3, indicating that modern recharge is more enriched than the older water collected from HS-1, consistent with paleoclimate information. The composition of the Wightman Well samples is central within the Stillwater group, suggesting that it may better represent the mixing endmember than HS-1. The composition of HS-1 is similar to that of artesian wells sampled in Dixie Valley, which also are presumed to be of older origin. Three of the Stillwater spring/stream samples have more enriched compositions similar to Smith-James Spring and may all be located in areas that tend to favor recharge from warmer season precipitation. These samples plot on or very close to the local meteoric water line, not exhibiting the nonequilibrium enrichment of the majority of samples, believed due to evaporation during precipitation or infiltration through the soil zone. This may mean that Smith-James Spring and the other three Stillwater samples are the product of very rapid recharge (probably through fractures) that may capture a higher proportion of precipitation from summer thunderstorms.

The chemical difference between water sampled at Smith-James Spring and at HS-1 may reflect additional differences in the recharge water, perhaps related to both space and time. The water at Smith-James Spring provides insight into the chemical nature of current recharge on the range. Though containing a significant component of water less than 50 years old (evidenced by the tritium content), the spring water has a surprisingly high dissolved solids load of about $600 \mathrm{mg} / \mathrm{l}$. A particular problem is the more than $50 \mathrm{mg} / \mathrm{l}$ concentration of both $\mathrm{Cl}$ and $\mathrm{SO}_{4}$, neither of which are major constituents of rock-forming minerals in the Sand Springs Range. The probable explanation lies in the position of the Sand Springs Range in the immediate downwind direction of Fourmile Flat and the Carson Desert at large. Aeolian deposition of fine material, particularly halite and gypsum, deflated from the salt flats must be an important process as the predominant northeast wind loses velocity and carrying power at ground level as it rises to pass over the range. Windblown silty material mantles several of the major depressions in the crest of the range (Nevada Bureau of Mines et al., 1965). This material is available to go into solution and be carried into the subsurface by rainfall.

Groundwater from HS-1, however, contains about half the dissolved solids load of water from Smith-James Spring, suggesting that the groundwater has a more dilute source. Three possibilities for this other source exist: recharge in the Fairview Peak-Slate Mountain range east of Fairview Valley, runoff from the Sand Springs Range, and/or recharge during glacial conditions. Lower salinity for recharge in the eastern mountain range is reasonable because it is farther downwind from the major dust source area, and is borne out by the salinity of Slate Spring located on the west side of Slate Mountain. This spring's chemistry (Nevada Bureau of Mines et al., 1965) is very similar to that of HS-1 and lower in TDS than Smith-James Spring. However, the recharge potential of the Fairview Peak-Slate Mountain uplift does not appear to be significantly larger than that of the Sand Springs Range (i.e., the elevations are similar), so there is no obvious reason to suggest that groundwater throughout Fairview Valley has its origin in the eastern range. 


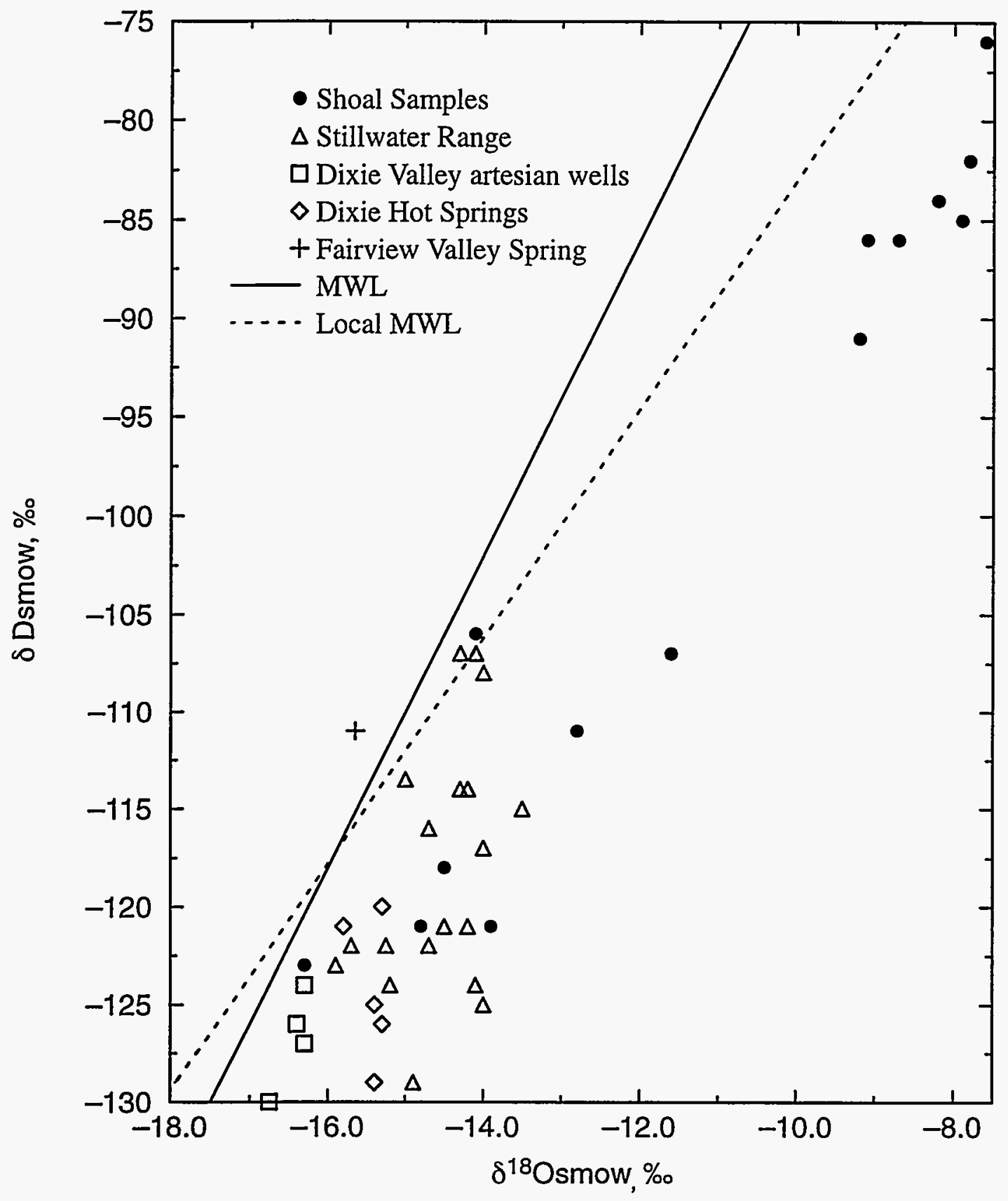

Figure 10. Stable isotope composition of samples from this study ("Shoal samples") plotted with stable isotope data from other wells and springs in the region, from University of Nevada (1980). The composition of several of the Shoal wells and springs (see Figure 4 to identify sample locations) is coincident with that of samples from the Stillwater Range, while the water from HS-1 is more depleted in heavy isotopes. The Stillwater Range samples are from springs and streams that are believed to represent relatively recent water. 
Recharge from runoff better fits the physical situation in Fairview Valley. The Sand Springs Range presents a very steep, abrupt mountain front on the western side, offering limited drainage area for runoff to Fourmile Flat. Conversely, there are well-developed networks draining most of the highland area and leading down to Fairview Valley on the east. HS-1 is actually directly downslope from the large drainageway known as GZ Canyon and is near an ephemeral channel that carries runoff from several other canyons to the south. Thus, it seems likely that recharge to the alluvium in the vicinity of HS-1 comes in large part by infiltration of runoff. Lower salinities are consistent with runoff because a larger volume of water is available to dilute dissolved dryfall encountered in streamcourses. Additionally, the carbon-14 at HS-1 suggests that much of the infiltration took place during the last glacial maximum, 16,000 to 20,000 years ago. During this period, Lake Lahontan covered the now dry basins to the west so that dust and therefore dryfall would be greatly reduced.

In contrast, groundwater discharging at Smith-James Spring has a chemical character consistent with recharge that has dissolved appreciable dryfall of salts deflated from the dry lakebeds. This implies more areally distributed infiltration, rather than concentrated along stream courses, and timing of infiltration consistent with dustier periods during the recent interglacial. This interpretation is consistent with the presence of tritium and the more enriched stable isotopic composition of the spring as compared to HS-1, indicating warmer temperatures of condensation for the recharging precipitation.

\section{REFLUX WATER CHARACTERISTICS}

As the other endmember of the $\delta \mathrm{D}-\mathrm{Cl}$ mixing line, the upper $\mathrm{H}-2$ samples reflect the composition of the reflux water. It is reasonable that some component of this water has been subjected to evaporation, accounting for its saline character, so the enriched isotopic composition is at least partly due to evaporative enrichment. The evaporation trajectory taken by a residual water depends on a number of atmospheric factors as well as the starting water composition, so the initial composition of the reflux water prior to evaporation cannot be determined. It is also likely that the upper $\mathrm{H}-2$ water is not actually the endmember, but is itself the product of mixing. $\mathrm{H}-2$ does not demonstrate markedly more kinetic enrichment than the other samples both in this and earlier work in the area, so that it is possible that some of the observed enrichment is also due to lower altitude precipitation. However, the climate in the bordering mountain ranges rather than the climate of the basin floor was believed to control water input to Lake Lahontan (Benson and Thompson, 1987), so low altitude precipitation is not consistent with that school of thought.

The reflux water sampled deeper in $\mathrm{H}-2$ has an isotopic composition that trends along the same line as the other samples, but has an inverse $\delta \mathrm{D}-\mathrm{Cl}$ relationship. The deepest, most saline water, collected $219 \mathrm{~m}$ bls, has the most depleted isotopic composition of the reflux water. The water becomes less saline and isotopically more enriched with shallower position in the well. Because these deeper $\mathrm{H}-2$ samples lie on the same isotopic trend as the other groundwater, the source of the reflux water is presumed to be the same as for the other samples (i.e., a mix of recharge water from the range and reflux brine from Fourmile Flat). However, the source of the solutes is apparently 
different, perhaps related to mineral dissolution in the lakebed sediments, and the distribution in the well may be density controlled because the most saline water occurs on the bottom. The deep H-2 samples have the oldest carbon-14 ages : 22,000 to 32,000 ybp uncorrected, 11,000 to $22,000 \mathrm{ybp}$ corrected for arid plants as discussed above (Table 2). The oldest water occurs at $205 \mathrm{~m}$, sandwiched between younger samples above and below. The younger dates are reasonably coincident with the last major Lahontan highstand around 13,000 ybp (Benson and Thompson, 1987). Though it is tempting to interpret these trends in the context of the development and movement of reflux brine in the basin, such conclusions cannot be drawn because the possibility of corroded casing makes the relationship of the well samples to in situ conditions unknown.

\section{IMPLICATIONS OF REFLUX BRINE ON TRANSPORT FROM THE SAND SPRINGS RANGE}

The impact of incorporating the presence of reflux water from Fourmile Flat into the conceptual model of transport from the Shoal site in the Sand Springs Range depends on the location of the cavity with respect to the groundwater divide beneath the range. If the cavity is on the east side of the divide, so that flow is toward Fairview Valley, hydrologic conditions to the west are of limited concern. If the cavity is on the west side of the divide, reflux water could have a major impact on predictions of contaminant transport.

In the presence of reflux brine, the fresh water flow from the recharge area is confined to a much thinner zone and all discharge occurs at springs located at the hinge line. In their numerical simulations comparing a fresh water case with the situation of saturated brine at the playa, Duffy and Al-Hassan (1988) found that the groundwater discharge at the hinge was more than doubled in the brine case. The presence of brine also causes the head to increase in the recharge zone as a result of restricted groundwater discharge. Thus, groundwater moving from the Sand Springs Range to Fourmile Flat will have less opportunity for vertical spreading and will be directed to the closest discharge point at the edge of the flat.

With its low recharge rates, the Shoal area represents a fairly extreme case of reflux parameters, leading to the possibility of the salt nose moving to the margin of the basin. This may in fact have occurred and account for the more saline nature of groundwater sampled from the Shoal site wells in the range (Nevada Bureau of Mines et al., 1965), as compared to water discharging at Smith-James Spring on the east side. Thus, the chemical similarity between PM-1 and H-3 may reflect mixing of small amounts of reflux brine with freshly recharged water, rather than simply similar water-rock reactions. Either way, the chemical evidence supports a connection between the test location and the western flow path, despite hydraulic head data suggesting an eastern flow direction (albeit under conditions of great uncertainty) (Nevada Bureau of Mines et al., 1965). If steady-state conditions have not yet been reached, the incursion of brine eastward could change the hydraulic relationship between the range and adjacent valleys. In particular, the predicted increase in head in the recharge zone caused by the restriction of the discharge zone could cause the potentiometric divide to migrate westward in time. Indeed, this may have already occurred and provide the explanation for the apparently contradictory chemical and hydraulic evidence regarding the location of the divide. The 
hydraulic head data indicating eastward flow from the test location may accurately reflect the current hydraulic situation, while the chemical data linking the site with the western flow system reflects relic conditions. The chemical tracers would not be representative of the new flow configuration until groundwater had traversed the distance to the first sampling point (HS-1), a time period estimated on the order of thousands of years (Nevada Bureau of Mines et al., 1965).

The current data leave unresolved the impact of reflux brine on the risk posed by contaminants at the Shoal site. Refluxing may have no impact on the site at all if the detonation occurred east of a stable groundwater divide. If the nuclear cavity is west of the divide, reflux water will shorten the flow path to springs at Fourmile Flat. However, there is also the possibility that refluxing will alter the basin's flow system, effectively closing the western flow path to contaminant transport from the site. In that case, the incursion of brine may actually have a beneficial effect in shunting Shoal contaminants into a much longer transport pathway to the accessible environment. 


\section{REFERENCES}

Benson, L.V. and R.S. Thompson, 1987. Lake-Level Variation in the Lahontan Basin for the Past 50,000 years. Quaternary Research, Vol. 28, pp. 69-85.

Chapman, J.B. and S. Hokett, 1991. Evaluation of Groundwater Monitoring at Offsite Nuclear Test Areas. Desert Research Institute, Water Resources Center Publication No. 45085, 82p.

Cohen, P. and D.E. Everett, 1963. A Brief Appraisal of the Ground-Water Hydrology of the Dixie-Fairview Area, Nevada. State of Nevada, Department of Conservation and Natural Resources, Ground-Water Resources-Reconnaissance Series Report 23, 40p.

Duffy, C.J. and A. Al-Hassan, 1988. Groundwater Circulation in a Closed Desert Basin: Topographic Scaling and Climatic Forcing. Water Resources Research, Vol. 24, No. 10, pp.1675-1688.

Eakin, T.E., 1965. Regional Ground-Water System in Southeastern Nevada. Geol. Soc. America Spec. Paper 82, p.51.

Herczeg, A.L., C.J. Barnes, P.G. Macumber and J.M. Olley, 1992. A Stable Isotope Investigation of Groundwater-Surface Water Interactions at Lake Tyrrell, Victoria, Australia. Chemical Geology, Vol. 96, pp. 19-32.

Jacobson, R.L., N.L. Ingraham and M.E. Campana, 1983. Isotope Hydrology of a Basin and Range Geothermal System. Desert Research Institute, Water Resources Center Publication No. 41087, $18 \mathrm{p}$.

Maxey, G.B., 1967. Hydrogeology of Desert Basins. Presented at Symposium on Groundwater Development in Arid Basins, Utah State University, Logan, Utah, March 16-17, pp. 1-22.

Maxey, G.B. and T.E. Eakin, 1949, Ground Water in White River Valley, White Pine, Nye, and Lincoln Counties, Nevada. Nevada State Engineer's Office, Water Res. Bull. 8, 59p.

Nevada Bureau of Mines, Nevada Mining Analytical Laboratory, and Desert Research Institute, 1965. Final Report: Geological, Geophysical, Chemical, and Hydrological Investigations of the Sand Springs Range, Fairview Valley, and Fourmile Flat, Churchill County, Nevada. U.S. Atomic Energy Commission Report VUF-1001, 369 p.

Papke, K.G., 1976. Evaporites and Brines in Nevada Playas. Nevada Bureau of Mines and Geology Bulletin 87, 35p.

University of Nevada, 1980. Environmental Isotope Hydrology of the Dixie Valley Geothermal System. In Geothermal Reservoir Assessment Case Study, Northern Basin and Range Province, Northern Dixie Valley, Nevada, Vol. III, pp. C-1 to C-26.

U.S. Atomic Energy Agency, 1964. Project Manager's Report, Project Shoal, Nevada. Nevada Operations Office Report NVO-11, 82p. + appendices. 
Winograd, I.J., 1962. Interbasin Movement of Ground Water at the Nevada Test Site, Nevada. U.S. Geological Survey Prof. Paper 450-C, pp.C108-C111.

Winograd, I.J. and W. Thordarson, 1975. Hydrogeologic and Hydrochemical Framework, South-Central Great Basin, Nevada-California, with Special Reference to the Nevada Test Site. U.S. Geological Survey Professional Paper 712-C, 126p. 


\section{DISTRIBUTION}

\section{U.S. Department of Energy}

Gylan Allen

Test Operations Division

Nevada Operations Office

U.S. Department of Energy

P.O. Box 98518

Las Vegas, NV 89193-8518

Kevin Cabble

Environmental Restoration Division

Nevada Operations Office

U.S. Department of Energy

P.O. Box 98518

Las Vegas, NV 98193-8518

Doug Duncan

Hydrology Program Manager

Office of Environmental Restoration

and Waste Management

Nevada Operations Office

U.S. Department of Energy

P.O. Box 98518

Las Vegas, NV 89193-8518

Donald Elle, Director

Environmental Protection Division

Nevada Operations Office

U.S. Department of Energy

P.O. Box 98518

Las Vegas, NV 89193-8518

Joseph N. Fiore, Ȧcting Assistant Manager

Office of Environmental Restoration

and Waste Management

Nevada Operations Office

U.S. Department of Energy

P.O. Box 98518

Las Vegas, NV 89193-8518

Steve Lawrence

Environmental Restoration Division

Nevada Operations Office

U.S. Department of Energy

P.O. Box 98518

Las Vegas, NV 89193-8518
Kevin Leary

Environmental Restoration Division

Nevada Operations Office

U.S. Department of Energy

P.O. Box 98518

Las Vegas, NV 98193-8518

John S. Ledbetter

Contracts Division

Nevada Operations Office

U.S. Department of Energy

P.O. Box 98518 , MS 505

Las Vegas, NV 89193-8518

Steve Leedom

Test Operations Division

Nevada Operations Office

U.S. Department of Energy

P.O. Box 98518

Las Vegas, NV 89193-8518

Steve Mellington, Director

Environmental Restoration Division

Nevada Operations Office

U.S. Department of Energy

P.O. Box 98518

Las Vegas, NV 89193-8518

Richard Pearl

Environmental Protection Division

Nevada Operations Office

U.S. Department of Energy

P.O. Box 98518

Las Vegas, NV 89193-8518

David S. Shafer

NV/Albuquerque Laboratories Division

Office of Southwestern Area Programs

U.S. Department of Energy

EM-452, Trevion II

Washington, D.C. 20585

Technical Information Resource Center

Nevada Operations Office

U.S. Department of Energy

P.O. Box 98518

Las Vegas, NV 89193-8518 


\section{U.S. Department of Defense}

David Bedsun

Defense Nuclear Agency

U.S. Department of Defense

P.O. Box 98539

Las Vegas, NV 89193-8539

\section{U.S. Environmental Protection Agency}

Deb Shaloud

Environmental Monitoring Systems Lab.

Office of Radiation Protection

U.S. Environmental Protection Agency

P.O. Box 93478

Las Vegas, NV 89193

\section{Lawrence Livermore National Laboratory}

Lee Davisson

Nuclear Chemistry Division

Lawrence Livermore National Laboratory

P.O. Box 808

L-237

Livermore, CA 94550

Greg Nimz

Lawrence Livermore National Laboratory

P.O. Box 808

MS L233

Livermore, CA 94550

\section{Los Alamos National Laboratory}

Joe Thompson

Los Alamos National Laboratory

INC-11, MS J514

P.O. Box 1663

Los Alamos, NM 87545

\section{U.S. Geological Survey}

Virginia Glanzman

U.S. Geological Survey

Box 2506, MS 913

Denver Federal Center

Denver, CO 80225
Randy Laczniak

U.S. Geological Survey

Water Resources Division

6770 S. Paradise Rd.

Las Vegas, NV 89119

Paul Orkild

U.S. Geological Survey

Box 2506, MS 913

Denver Federal Center

Denver, CO 80225

Doug Trudeau

U.S. Geological Survey

Water Resources Division

6770 S. Paradise Rd.

Las Vegas, NV 89119

\section{Desert Research Institute}

Roger Jacobson

Desert Research Institute

Water Resources Center

P.O. Box 19040

Las Vegas, NV 89132-0040

Marjory Jones

Desert Research Institute

Water Resources Center

P.O. Box 60220

Reno, NV 89506-0220

Paul Seaber

Desert Research Institute

Water Resources Center

P.O. Box 19040

Las Vegas, NV 89132-0040

\section{Reynolds Electrical \& Engineering Co.}

Martha DeMarre

Chief, Document Research Section

Health Protection Dept.

Reynolds Electrical \& Engineering Co.

P.O. Box 98521

Las Vegas, NV 89193-8521

Brian Dozier

Reynolds Electrical \& Engineering Co.

2501 Wyandotte

Mercury, NV 89102 


\section{State of Nevada}

Larry Franks

Nevada State Health Department

Radiological Health Section

620 Belrose Avenue

Las Vegas, NV 89158

\section{LIBRARIES}

Archives

Getchell Library

University of Nevada, Reno

Beverly Carter

MacKay School of Mines Library

University of Nevada, Reno

Stead Library

Desert Research Institute

Reno, Nevada

Southern Nevada Science Center Water Resources Center, Library P.O. Box 19040

Las Vegas, NV 89132-0040

Document Section, Library University of Nevada, Las Vegas 4505 Maryland Parkway

Las Vegas, NV 89154
Annie Kelley

State Documents Department

Nevada State Library

Capitol Complex

Carson City, NV 89710

Water Resources Research Archives

University of California

Room 40, North Gate Hall

Berkeley, CA 94720

\section{International Technology Corp.}

Rick Waddell

Geotrans

clo IT

4330 Valley View

Suite 112

MS-439

Las Vegas, NV 89103-4047

Joe Yeasted

International Technology Corporation 4330 S. Valley View

Suite 114

Las Vegas, NV 89103

Richard M. Deshler

International Technology Corporation 4330 S. Valley View

Suite 114

Las Vegas, NV 89103-4047 